\title{
Biobutanol Standardizing Biodiesel from Waste Animal Fat
}

\author{
Vladimír Hönig'*, Martin Pexa², Zdeněk Linhart ${ }^{3}$ \\ 'Department of Chemistry, Faculty of Agrobiology, Food and Natural Resources, \\ ${ }^{2}$ Department for Quality and Dependability of Machines, Faculty of Engineering, \\ ${ }^{3}$ Department of Management, Faculty of Economics and Management, \\ Czech University of Life Sciences Prague, Czech Republic
}

Received: July 10, 2015

Accepted: September 3, 2015

\begin{abstract}
This article contains measurements proving the benefits of biobutanol in methyl ester fuels made from animal fats. Generally, methyl esters from animal fats have much worse fuel parameters than rape seed methyl esters, for example. The tested biobutanol in this article has improved properties of produced methyl ester. Butanol is more suitable than bioethanol for diesel engines. Fuel properties of density, kinematic viscosity, behaviour of fuel under low temperatures, and flash point and cetane number for different butanol content in fuel blend were tested. It was shown that butanol improves the quality of methyl ester fuels from animal fats, especially its behaviour under low temperatures. Adding biobutanol to blends creates from animal fat methyl ester a more attractive fuel. Furthermore, using animal fat waste for methyl ester production and waste lignocellulose for biobutanol production are considered to be advantageous by the EU as being more sustainable for isolation of waste transfers between regional, natural, and industrial circles of the circular economy.
\end{abstract}

Keywords: butanol, animal fat methyl ester, kinematic viscosity, cold filter plugging point, cetane number

\section{Introduction}

It is believed that climate warming is caused by greenhouse gasses (GHG). Consumption of energy from 15,628 Mt of GHG in 1973 has since increased to $31,342 \mathrm{Mt}$ in 2011. Consequences are seen at increased contents of GHG in the air. Production of the six most important gasses on the list of the Kyoto Protocol has increased by $168 \mathrm{ppm}$ to $446 \mathrm{ppm}$ of $\mathrm{CO}_{2}$ equivalent, as opposed to the pre-industrial period (Environmental Agency of the EU). The EU is one of the main representatives fighting for its decrease, besides Kyoto Protocol and IPCC efforts. Nature, agriculture, energy, transport, and industry are the main polluters. Transport has produced one-third of this increase of emissions.

*e-mail: honig@af.czu.cz
More precisely, a report titled "The contribution of transport to air quality TERM 2012" (Environmental Agency of EU, 10/2012) defines the contribution of transport to air pollution in $27 \mathrm{EU}$ states at $24 \%$ of $\mathrm{CO}_{2}$ equivalent. USA transport pollution is $34 \%$ of total pollution. Replacement of fossil fuels by renewable energy or biofuels for industrial and transportation purposes may decrease GHG emissions considerably [1]. Still, efforts proving GHG savings of biofuels and renewable energies are needed. Efficiency of combustion of biofuels in engines must be clarified before its use is broadened above recent levels [2].

Public opinion is afraid that biodiesel will harm engines, food prices, or nature. Biodiesel is fatty acids methyl ester (FAME), which is produced by standardised technology. Its core element is catalysed transesterification of glycerides, which are present in raw materials [3]. 
Reaction occurs between fatty acids of soybeans, oilseed, rape seed, and sunflower, beef, poultry, fish or pork fats, for example, and methanol [4-6]. Oils used for frying also can be subject to transesterification. Waste animal fats are accessible without legal restrictions in a few cafilerias in large volumes for transesterification, allowing biofuel to be competitive with fossil fuel. Similarly, inedible oils from waste of rice or coffee processing and used cooking oils can be used for transesterification for biodiesel production, but in limited and territorially dispersed volumes.

The biggest volume of cafileria origin waste animal fats are beef and pork. Waste poultry and fish fats have smaller volumes. Waste animal fats contain high volumes of free acids, causing high acidity numbers and high freezing points surprisingly above other animal fats. Free fatty acids make transesterification of waste animal fats difficult due to soap in shape of stable emulsions complicating separation of parts, increasing consumption of catalysers and decreasing the volume of processed methyl esters. Therefore, the content of free fatty acids for alkaline-catalysed transesterification must be minimised. Firstly, acid-catalysed esterification by methanol generates methyl esters and water from free fatty acids of waste fats $[7,8]$. Traditional technology of methyl ester production from waste animal fats proceeds as follows:

1. Acid-catalysed esterification of free fatty acids

2. Alkaline-catalysed transesterification of fats

3. Methyl ester purification

4. Drying

5. Distillation of methyl ester

Oleic, linoleic, and linolenic fatty acids for transesterification of vegetable oils are replaced by palmitic and stearic fatty acids in waste animal fats for transesterification. Therefore, strong mineral acids like $\mathrm{H}_{2} \mathrm{SO}_{4}$ are used as catalysers for transesterification of waste animal fats [9].

Only differences up to standard EN 14214 (FAME) for diesel engines should appear in composition of methyl esters (Table 1). But AFME has bad low temperature properties, and carbonisation shortens engine life cycles so that decarbonisation of engines - including injection facilities is increasing costs above the decreased price of fuel [10, $11]$.

Thermo-oxidation stability is another important feature for aging fuel, especially if oxygen, high temperatures, or the catalyst effect of metals are present. Due to low storage temperature $\left(5-20^{\circ} \mathrm{C}\right)$, fuel degradation is not significant, but higher engine temperatures $\left(60-80^{\circ} \mathrm{C}\right)$ increase oxidation $[12,13]$. Oxidation under high temperatures produces sediments, that can't be diluted. Therefore, clogging and subsequent failure of the various elements of the fuel system may occur $[14,15]$.

Total volume of biodiesel produced from animal fats (animal fat methyl esters, or AFME) is about $2 \%$ of all fuels only. Therefore, the low price AFME decreases the price of diesel not significantly, even if more than $80 \%$ of it is caused by animal fats. Still, producers search for this little gain from non-edible or waste fats and oils.

AFME is fuel only for diesel engines. Development of renewable fuel for gasoline engines is oriented on
Table 1. Comparison of select parameters of rapeseed oil methyl ester (RME) and animal fats methyl ester (AFME) with standard EN 14214 for fatty acid methyl ester (FAME).

\begin{tabular}{|c|c|c|c|}
\hline Parameter & $\begin{array}{c}\text { FAME } \\
(\text { EN 14214) }\end{array}$ & RME & AFME \\
\hline $\begin{array}{l}\text { Content of methyl esters } \\
(\% \text { wt.) }\end{array}$ & $\min .96 .5$ & 98 & $>99.5$ \\
\hline $\begin{array}{l}\text { Content of monoglycerids } \\
\text { (\% wt.) }\end{array}$ & $\max .0 .8$ & 0.6 & 0.01 \\
\hline Content of water $\left(\mathrm{mg}^{-1} \mathrm{~kg}^{-1}\right)$ & $\max .500$ & 300 & 100 \\
\hline $\begin{array}{l}\text { Total content of impurities } \\
\left(\mathrm{mg} \cdot \mathrm{kg}^{-1}\right)\end{array}$ & $\max .24$ & 10 & 4 \\
\hline Content of phosphorus $\left(\mathrm{mg} \cdot \mathrm{kg}^{-1}\right)$ & $\max .4 .0$ & $<0.5$ & $<0.5$ \\
\hline Content of sulphur $\left(\mathrm{mg} \cdot \mathrm{kg}^{-1}\right)$ & $\max .10$ & 4 & 8 \\
\hline Content of $\mathrm{Na} / \mathrm{K}\left(\mathrm{mg} \cdot \mathrm{kg}^{-1}\right)$ & $\max .5 .0$ & $<0.5$ & $<0.5$ \\
\hline
\end{tabular}

bioethanol, which has for some time been used as a blend with gasoline. Therefore, biobutanol seems to be one of the good alternatives of alcohols for ignition engines. Bioutanol is fuel with good perspective for blends with gasoline replacing commercially frequently used bioethanol. Biobutanol (n-butanol, butan-1-ol) can be produced from the same raw materials as bioethanol, but many of its properties outperform bioethanol in gasoline fuel blends. Besides sugar beet, sugar cane, maze, wheat, cassava, and sorghum are straw and grass, including fast-growing cellulose sources that will be used as raw materials for biobutanol production in the future. Therefore, biobutanol is considered a second-generation biofuel because waste materials can be used for its production (as it the case for bioethanol, too).

The USA is a leader in developing specific investment plans of production facilities for the new generation of biobutanol, bioethanol, and other biofuels. The U.S. government is planning to support the development of biofuels of a new generation by $\$ 800$ million US. From that, $\$ 480$ million should be invested to pilot biorefineries, and $\$ 180$ million to support projects of mass production of new generation biofuels. Therefore, experts forecast that costs of alcohols produced from cellulose will reach a level of costs of alcohols produced from maize in five years. Still, production of biofuel from non-agricultural waste is in the beginnings and needed investments will be high. Therefore, it is expected that associations of communities and farmers in U.S. rural areas will invest in reconstruction of former distilleries and sugar-producing factories into biobutanol facilities with a capacity of from 5 to 30 million gallons per year (1.14 million hl per year). These local biorefineries may easily conform to conditions of environmental protection norms, especially of air quality. The USA is planning to produce 36 million of gallons of biofuels per year (136 million t) by 2022 . About $20 \%$ of recent U.S. engine fuel consumption will have no impact on food market prices. All annual U.S. production of maize would be processed 
into biofuels without using other biomass. Therefore, the transition to biomass from cellulosic or lignocellulosic raw materials is essential for the USA. Similarly, the EU would not be able to fulfil its targets of renewable fuels only from first generation biofuels.

Processing of wastes contributes to environmental protection, while price of produced biofuels decreases costs of environmental protection. For example, cleaning maize produces 10 million $t$ of waste at the expense of the environment. Similarly, the U.S. dairy industry produces 27 million $t$ of waste whey with high content of sugar from cheese production per year. Waste processing costs of this whey is very expensive, besides consuming a large amount of oxygen, which makes this pollution painful. These examples are showing cheap raw materials out of wastes for production of hydrogen and alcohols for biofuels especially of biobutanol.

Biobutanol, as opposed to gasoline or butanol from crude oil, has not been profitable until now. The price of biobutanol should fit interval \$0.19-0.25 per 1 without subsidies (EUR 0.14-0.19) if the new generation of waste biomass processing can be applied. The EU price of bioethanol fluctuates between $€ 0.5$ and 0.6 per 1 . No adaptation costs will appear in the processing industry if bioethanol production stops being replaced by production of biobutanol as both technologies are similar. $42 \%$ of additional energy is produced from maize if butanol is processed oppose to bioethanol (2301 of bioethanol or 3801 of biobutanol is produced from $1 \mathrm{t}$ of maize). Some fuel producers, for example DuPont or BP, prefer biobutanol more than bioethanol and are trying to put it on the market in cooperation with British Sugar from Associated British Foods Group. Second generation biobutanol probably will be produced by new biotechnology with higher conversion due to biocatalyst (Butamax project). The efficiency of direct fermentation for biobutanol production from simple sugars or enzymatic fermentation or hydrolytically processed polysaccharides is an objective of projects that are developing the technology [16-18].

Both bioethanol and biobutanol are produced from the same raw materials by ethanol fermentation of simple sugars, which is called the ABE (aceton-butanol-ethanol) process under the action of Clostridium acetobutylicum [19].

Raw materials for $\mathrm{ABE}$ fermentation are:

1. Starchy (potatoes, corn, wheat, rice)

2. Sugary (sugar beet molasses, whey)

3. Lignocellulosic (straw, wood)

The second generation biofuels produce currently both positive and negative emotions (especially ethanol but also butanol). Different materials containing saccharidic cellulose (e.g., straw or waste, paper, and energy crops) will be the main source of raw materials for manufacturing of bioalcohols. Cellulose must be released from the lignocellulosic matrix and its subsequent cleavage to glucose units is done either chemically or enzymatically, being more costly opposed to conventional saccharidic sources [20].

Biobutanol has up to $31 \%$ higher energy content and contributes to nearly $95 \%$ of the energy of biofuels, as
Table 2. Fundamental parameters of diesel, gasoline, and biobutanol.

\begin{tabular}{|l|c|c|c|c|}
\hline \multicolumn{1}{|c|}{ Parameter } & Diesel & Gasoline & Bioethanol & Biobutanol \\
\hline $\begin{array}{l}\text { Cetane } \\
\text { number }\end{array}$ & $>51$ & - & 7 & 17 \\
\hline $\begin{array}{l}\text { Octane } \\
\text { number RON }\end{array}$ & - & $91-100$ & 108 & 94 \\
\hline $\begin{array}{l}\text { Oxygen } \\
\text { content, }(\% \mathrm{wt} .)\end{array}$ & - & $<2.7$ & 34.7 & 21.6 \\
\hline $\begin{array}{l}\text { Boiling point, } \\
\left({ }^{\circ} \mathrm{C}\right)\end{array}$ & $\begin{array}{c}163- \\
357\end{array}$ & $30-215$ & 78 & 118 \\
\hline $\begin{array}{l}\text { Melting point, } \\
\left({ }^{\circ} \mathrm{C}\right)\end{array}$ & - & - & -114.4 & -88.6 \\
\hline
\end{tabular}

Table 3. Fuel properties of gasoline, diesel, butanol and FAME.

\begin{tabular}{|l|c|c|c|c|}
\hline \multicolumn{1}{|c|}{ Parameter } & Gasoline & Diesel & Butanol & FAME \\
\hline $\begin{array}{l}\text { Chemical } \\
\text { composition }\end{array}$ & $\mathrm{C}_{4}-\mathrm{C}_{12}$ & $\mathrm{C}_{8}-\mathrm{C}_{25}$ & $\mathrm{C}_{4} \mathrm{H}_{9} \mathrm{OH}$ & $\begin{array}{c}\text { methyl esters } \\
\mathrm{C}_{12}-\mathrm{C}_{22} \text { of } \\
\text { fatty acids }\end{array}$ \\
\hline $\begin{array}{l}\text { Density at } 15^{\circ} \mathrm{C}, \\
\left(\mathrm{kg} \cdot \mathrm{m}^{-3}\right)\end{array}$ & $720-775$ & $\begin{array}{c}820- \\
845\end{array}$ & 813.57 & $860-900$ \\
\hline Flash point, $\left({ }^{\circ} \mathrm{C}\right)$ & -45 & $\min .55$ & 35 & min. 101 \\
\hline $\begin{array}{l}\text { Calorific value, } \\
\left(\mathrm{MJ} \cdot \mathrm{dm}^{-3}\right)\end{array}$ & 32.4 & 35.8 & 27.0 & 33.4 \\
\hline $\begin{array}{l}\text { Calorific value, } \\
\left(\mathrm{MJ} \cdot \mathrm{kg}^{-1}\right)\end{array}$ & 43.3 & 42.1 & 33.1 & 38.2 \\
\hline
\end{tabular}

opposed to bioethanol with $75 \%$. Biobutanol has higher calorific value than bioethanol, is not hygroscopic, and its characteristics are close to gasoline, allowing to use it as $100 \%$ biobutanol fuel.

Biobutanol fuel is safer due to lower vapour pressure than bioethanol. Biobutanol, unlike bioethanol, does not absorb water and freezes at $-89^{\circ} \mathrm{C}$. The transport of biobutanol by fuel pipeline systems, as opposed to bioethanol, causes no risk of corrosion and water separation. Biobutanol is biodegradable and poses no threat to the environment as it is of natural origin. Biobutanol can be added in higher concentrations in gasoline and hypothetically can be added in higher volume to diesel, unlike bioethanol [21].

Therefore, the objective of this article is to study the impact of biobutanol AFME fuel blend parameters.

Blends of hydrocarbon fuel and biobutanol are caused by the different chemical natures (Table 2). Low reactivity (cetane number), which must be increased by special additives, is the main problem [22].

There are many options for using alcohols in fuels. For example, E95 fuel consisting of 95\% ethanol and 5\% additives promotes lubricity and reactivity. It is also possible to use a bi-fuel system with separate tanks. It consists of injecting alcohol into the combustion chamber simultaneously with a separate injector for diesel. 


\section{Experimental Procedures}

Waste pork fat was melted and sterilised under high $0.3 \mathrm{MPa}$ pressure and temperature above $130^{\circ} \mathrm{C}$ during minimally 20 minutes. This was followed drying until porridge appeared, from which extraction processes separated fat and animal powder. Pressure was decreased gradually to dry all moisture from the sample. The dried sample was warmed at $80^{\circ} \mathrm{C}$ and put under $300 \mathrm{~kg} \cdot \mathrm{cm}^{-2}$ pressure. Liquid fat appeared after releasing the pressure, but it became solid again at $40-50^{\circ} \mathrm{C}$. A higher acidity number differentiates fat obtained by this procedure from properties of homogeneous fats. Water was removed from fat and impurities in decanters.

Methanol:fat 10:1\% wt. with 2-3\% wt. of sulphur acid was blended under a temperature of $90-95^{\circ} \mathrm{C}$ for transesterification during 6-7 hours to reach $90 \%$ of methyl esters. Esterification was performed by warming in ballons with feedback water cooler.

Tested n-butanol (further called butanol) was in p.a. quality (LachNer, Ltd). Furthermore, tetranitromethan (Sigma-Aldrich, Ltd.) was used. Parameters of the resulting blend were evaluated according to standards EN 590, valid for diesel, and EN 14214 for FAME.

The following tests of blends were made:

1. Density at $15^{\circ} \mathrm{C}$ by EN ISO 3675

2. Kinematic viscosity at $40^{\circ} \mathrm{C}$ by EN ISO 3104

3. CFPP - Cold filter plugging point by EN 116

4. Flash point by EN 2719

5. Oxidation stability of AFME according to EN 15751

6. Oxidation stability of butanol by EN ISO 7536

7. Cetane number by EN ISO 5165

Oxidation stability of AFME, according to the Rancimat method, was compliant with EN15751 and may be used for both pure FAME and a blend of FAME with diesel [23]. The sample located under $110^{\circ} \mathrm{C}$ was exposed to a $10 \mathrm{dm}^{3} \cdot \mathrm{h}^{-1}$ stream of air bubbles. Conductivity of liquid in a container with distilled water retaining products of oxidation was measured by an electrode. Conductivity is influenced by carboxyl acids emerging during oxidation and resulting in induction period.

Oxidation stability of butanol was assessed according to EN ISO 7536 for gasolines and ethanol gasoline blends in $25 \mathrm{ml}$ samples under $100^{\circ} \mathrm{C}$ under oxygen pressure of $690 \mathrm{kPa}$. Measured time until the oxidation reaction with a decrease of oxygen pressure in a container is called induction period.

There is no standard for measuring oxidation stability of FAME blend with alcohols. Therefore, AFME and butanol were measured independently.

\section{Results and Discussions}

Density, CFPP, cetane numbers, and oxidation stability were measured directly without any statistic processing according to standard EN 590. The value of kinematic viscosity and flash point was assessed by three analyses. Final value was calculated as the average of the three measurements.

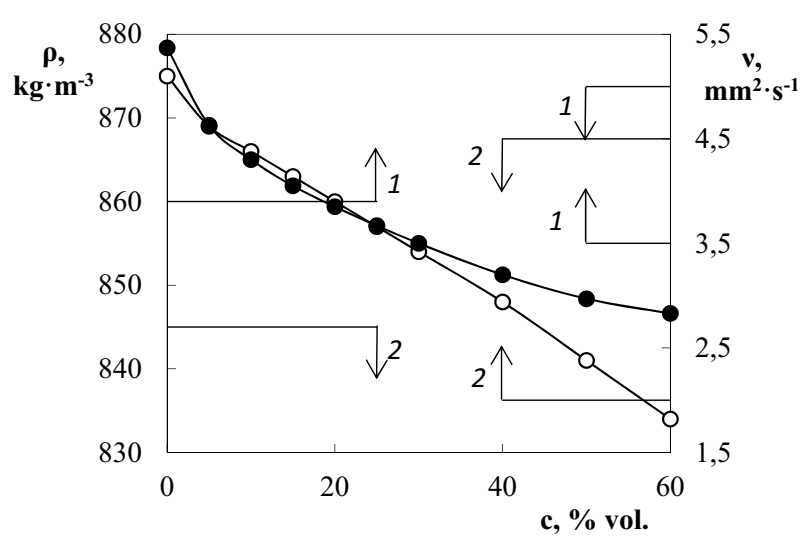

Fig. 1. Density and viscosity of AFME with butanol. Content of butanol in \% vol. is on horizontal axis, density at $15^{\circ} \mathrm{C}$ in $\mathrm{kg} \cdot \mathrm{m}^{-3}(\mathrm{O})$ is on main vertical axis, and kinematic viscosity for $40^{\circ} \mathrm{C}$ in $\mathrm{mm}^{2} \cdot \mathrm{s}^{-1}(\bullet)$ is at right vertical axis.

Fig. 1 shows the impact of butanol on density and kinematic viscosity of AFME in comparison with standard values of EN 14214 for FAME and AFME marked by number 1, and according to EN 590 for diesel, which are marked by the number $2[10,24]$.

The value of density influences engine power because injection pumps deliver volume. Therefore, consumption of fuel increases with decreasing density. The higher the content of butanol, the lower the density of butanol and diesel blend, and the decrease of density corresponds with differences of densities of diesel and butanol.

In the case of kinematic viscosity a different course of decline has appeared. The lower the density and viscosity of FAME from animal fats the less damage to the fuel system, especially during low temperatures.

Minimal density according to EN 14214 is $860-900$ $\mathrm{kg} \cdot \mathrm{m}^{-3}$ with $15^{\circ} \mathrm{C}$ and kinematic viscosity $3.5-5.00 \mathrm{~mm}^{2} \cdot \mathrm{s}^{-1}$ at $40^{\circ} \mathrm{C}$. Below standard values causes damage to moving parts of the fuel system. FAME has significantly better lubricity in comparison to diesel. Values of lubricity of blends are outside the range of measurement methods according to EN ISO 12156-1 for diesel. Therefore, EN 14214 for all methods of measuring does not measure lubricity. This also is true for blends of biodiesel with butanol so that a higher content of butanol than ethanol can be used in diesel blend [6].

Lower kinematic viscosity due to butanol in blend improves pumping of fuel, transition through a fuel filter, and distribution of fuel in a cylinder. Kinematic viscosity of fuel blends to $60 \%$ vol. butanol in AFME is compliant with EN 590 for diesel, which is still in accordance with lubricity standards for moving parts of a fuel system.

Low-temperature properties of fuel are assessed using the cold filter plugging point (CFPP), which is the lowest temperature in allowing for a predefined volume of fuel in a predefined time through a standardised filtration facility. Therefore, use of AFME in winter is limited. This problem can be solved by using additives or by blending AFME with diesel or biodiesel from select vegetable oils [25]. 
Pure AFME has very bad low-temperature properties due to high content of saturated fatty acids. Additives are not sufficient to solve this well-known disadvantage. The correct proposed method of butanol blends positively improves CFPP value as crystallisation of pure butanol is $88.6^{\circ} \mathrm{C}$ and tested samples with volume above $65 \%$ vol. were behind the threshold of measurability. The low melting point of butanol improves CFPP up to winter quality of FAME according to EN 14214 (Fig. 2, number 1), especially above $25 \%$ vol. of butanol in fuel blend. Tested samples under low temperatures were resistant to separation of fuel fractions, which is known from ethanol fuel blends. It is not needed to use co-solvents as no separation of alcohol and methyl ester layers in fuel has occurred during tests under low temperatures. The blend of AFME and butanol is stable even at very low temperatures. No stabilizing additives need be used compared to bioethanol blends [26].

Flash point assessing fuel according to safety standards EN 14214 for FAME exceed the minimal level if more than $2 \%$ vol. of butanol is in fuel blend. The minimal level for diesel according to EN 590 was exceeded approximately between 10 to $15 \%$ vol. of butanol. This safety value remains unchanged at the level of boiling point of butanol if its volume in fuel blend increases. Therefore, the AFME fuel blend above $15 \%$ vol. of butanol stays in the second inflammable class. The changed flash point has no impact on engine power.

Limits (Fig. 2) according to standard EN 14214 for FAME and AFME are marked by number 1 , and according to EN 590 for diesel are marked by number 2 .

The induction period of oxidation stability of produced AFME has reached approximately 48 minutes. But oxidation stability of FAME according to EN 14214 is a minimal eight hours under $110^{\circ} \mathrm{C}$. Pure alcohols are stable from the oxidation point of view and its blends with AFME are not risky from an oxidation stability point of view. The higher content of alcohols, the higher oxidation stability of AFME blends with diesel. The induction period for butanol in p.a. quality was above 25 hours. This value corresponds to the measurement of other authors [27].

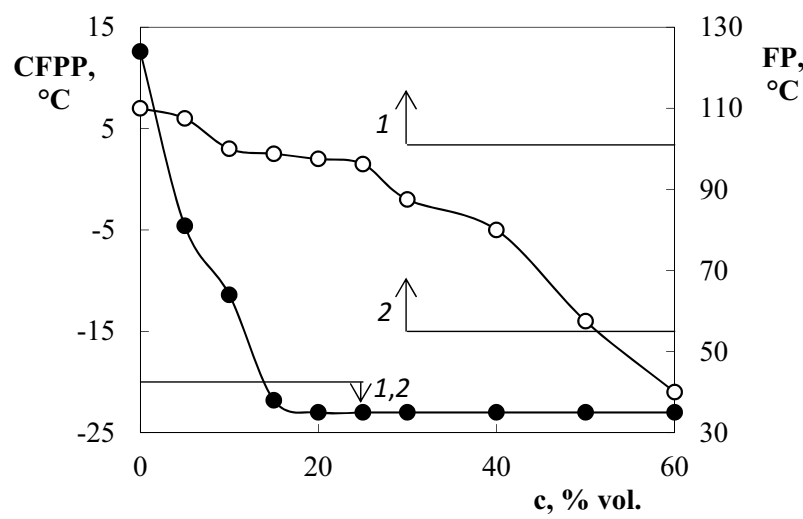

Fig. 2. CFPP (Cold Filter Plugging Point) and flash point (FP) of AFME with butanol. Butanol content in \% vol. is on horizontal axis, temperature of lost filtration ability (CFPP) in ${ }^{\circ} \mathrm{C}$ (०) is at left vertical axis, and temperature of flash point in ${ }^{\circ} \mathrm{C}$ $(\bullet)$ is at left vertical axis.
Table 4. Cetane numbers corresponding to volume of tetranitromethan additive in AFME fuel blend with butanol.

\begin{tabular}{|l|c|c|}
\hline $\begin{array}{c}\text { Butanol content in } \\
\text { sample }\end{array}$ & $\begin{array}{c}\text { Additive content } \\
\text { in sample }\end{array}$ & $\begin{array}{c}\text { Cetane } \\
\text { number }\end{array}$ \\
\hline $\begin{array}{l}1(20 \% \text { vol. } \\
\text { butanol in AFME) }\end{array}$ & 0.05 & 51.8 \\
\hline $\begin{array}{l}2(30 \% \text { vol. } \\
\text { butanol in AFME) }\end{array}$ & 0.1 & 51.2 \\
\hline $\begin{array}{l}3(40 \% \text { vol. } \\
\text { butanol in AFME) }\end{array}$ & 0.25 & 50.5 \\
\hline $\begin{array}{l}4(50 \% \text { vol. } \\
\text { butanol in AFME) }\end{array}$ & 0.4 & 51.1 \\
\hline
\end{tabular}

The higher the volume of saturated fatty acids, the higher the cetane number of fuel. The higher the cetane number, the easier it is to start, the more silent its power, the more stable it runs, and the lower the consumption by the engine, along with decreased emissions - especially $\mathrm{NO}_{\mathrm{x}}$ and particles.

The higher the butanol content, the lower the cetane number of fuel blend [22]. The minimal value of cetane number for diesel fuels is 51 according to EN 590. EN 14214 for pure FAME defines the same minimal cetane number. Therefore, a straight horizontal line (Fig. 3) offers the minimal cetane number for evaluation of differences of measured values. Especially if content of butanol is above $20 \%$, the cetane number does not reach the minimal value. Therefore, fuel additives like tetranitromethan, n-butylnitrate, tetralinhydroperoxid, or others are needed to make the fuel compliant with standard EN 590 and EN 14214. The impact of tetranitromethan, which was used in experiments, is seen in Figs. 3, 4, and 5. Numbers 1, 2, 3, and 4 (Fig. 3) show an increased cetane number of AFME with butanol to compliant level by EN 590 and EN 14214. Volume of used tetranitromethan is shown in Table 4.

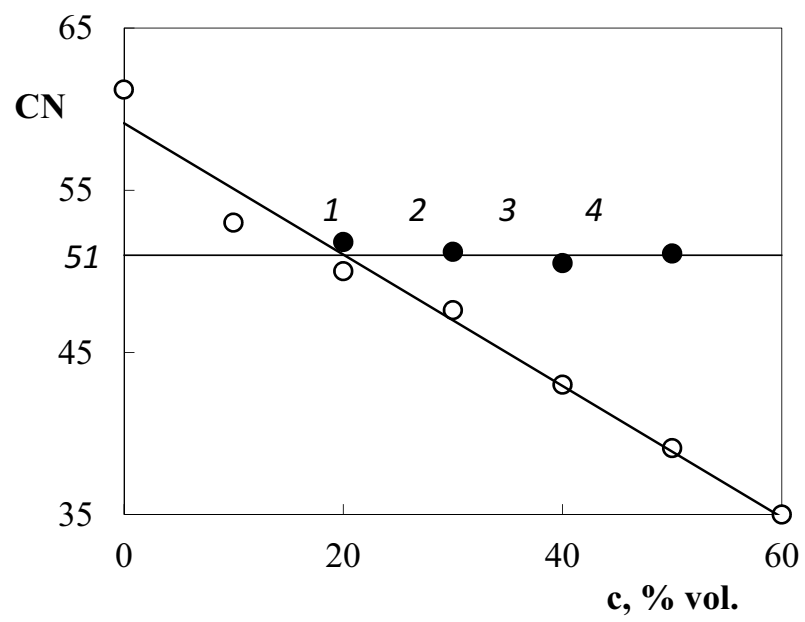

Fig. 3. Cetane number $(\mathrm{CN})$ of AFME fuel blend with butanol. Content of butanol in \% vol. is at horizontal axis, cetane numbers of AFME and butanol fuel blend are marked ( $\circ$ ) with values at left vertical axis, and increased cetane number by additive is marked $(\bullet)$. 


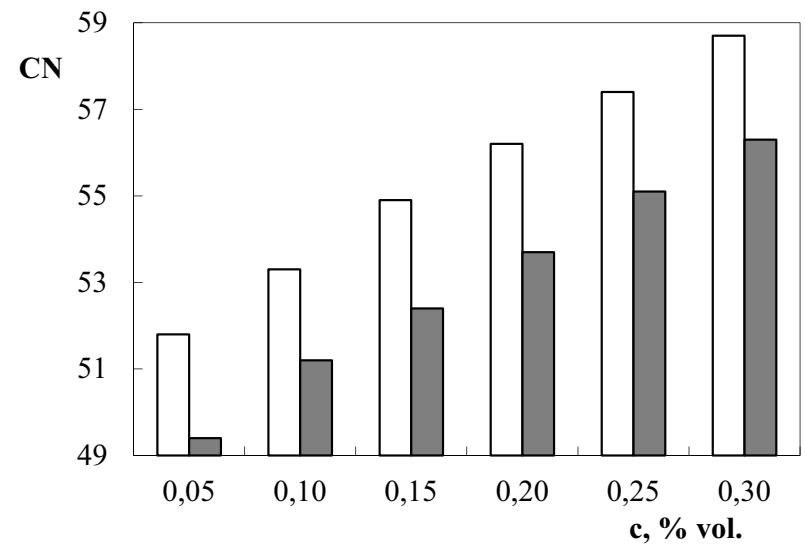

Fig. 4. Increasing cetane number of AFME fuel blend with butanol.

Tetranitromethan in \% vol. is at horizontal axis and value of cetane number for AFME fuel blends with $20 \%$ vol. (white) and $30 \%$ vol. (grey) of butanol are at vertical axis.

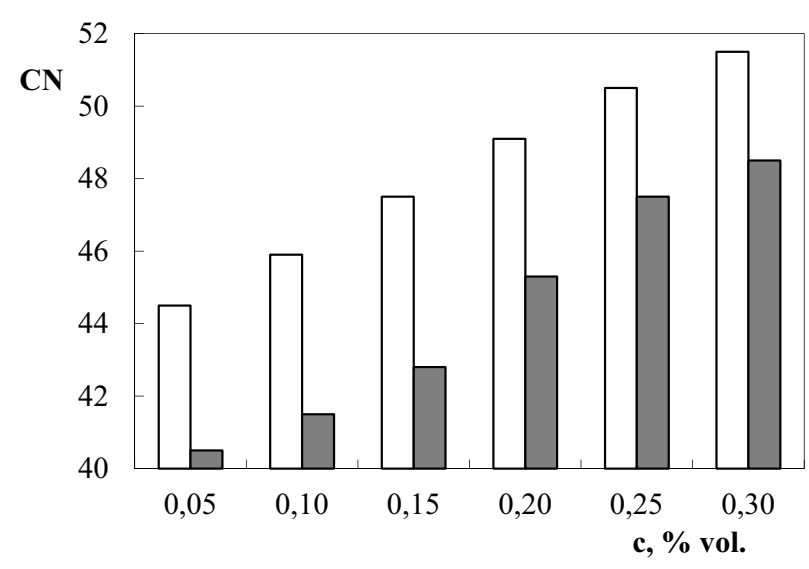

Fig. 5. Increasing cetane number of AFME fuel blend with butanol.

Tetranitromethan in \% vol. is at horizontal axis and value of cetane number for AFME fuel blends with $40 \%$ vol. (white) and $50 \%$ vol. (grey) of butanol are at vertical axis.

Tetranitromethan was tested also with other concentrations of fuel blends according to the method defined by EN ISO 5165. Cetane number of AFME blend with $20 \%$ vol., $30 \%$ vol., $40 \%$ vol., and 50\% vol. has increased (Figs. 4 and $5)$.

But butanol has lower calorific value compared to AFME (Table 3). Calorific value of ethanol is about $20 \%$ less than diesel fuel, but higher than the calorific value of bioethanol [26].

Therefore, the higher the concentration of butanol in blends with AFME, the lower the power plus increased fuel consumption, and irregular running of an unmodified engine would occur. Butanol in AFME fuel blends up to a maximum $50 \%$ vol. may offset all these negative features of engine power. Butanol may serve as an additive in lowpercentage AFME blends with other combustible fuels in engines.

\section{Conclusions}

We confirmed that animal fat from cafilerias is useful material for transesterification. Longer stored fat from slaughterhouse waste contains a high amount of free fatty acids. This fact has confirmed both regular analysis from cafilerias and acid-catalysed transesterification. Found differences of vegetable oils and animal fats, eventually methyl esters made out of them are caused by different contents of fatty acids in glycerids. Therefore, we may conclude that animal fats from cafilerias are a useful source for production of biofuels, but many problems must be solved during transesterification. Waste animal fat cannot be used as food and high volumes are concentrated in a few places. These are essential advantages for biofuel production.

Biobutanol is useful in fuel blends for engines. Butanol in a fuel blend with methyl ester from waste animal fats has improved its low temperature properties. Simultaneously, the blend is stable under low temperatures. No separated layers of alcohol and methyl ester were observed during tests under low temperatures. Such a stable blend does not require any co-solvents known from bioethanol fuel blends. Also, oxidation stability of the AFME fuel blend was inherited from alcohols. The content of butanol in fuel blend is limited by cetane number, which must be increased by using additives. Tetranitromethan has been successfully tested. Additives are needed under 20\% volume of butanol in fuel blend to comply with fuel standards. Density and viscosity of fuel blend were not threatened by content of butanol in AFME fuel blend from the point of view of both engine and fuel systems. AFME has very high lubricity above the level according to EN ISO 12205 for diesel. Therefore, moving parts of a fuel system are not endangered if the higher volume of butanol is in a fuel blend. The flashpoint of FAME is $\min 101^{\circ} \mathrm{C}$ according to standard EN 14214, which indicates a flammable hazard class IV. The higher the content of butanol, the higher the flammable hazard (up to class II). Even such a decrease of flashpoint has a negative impact on engine power.

Although the price of butanol is bit higher, this is offset by the minimisation of negative effects on engine and fuel systems, especially under low temperatures. AFME in fuel blend can also be used under low temperatures and its price is lower as its source is waste. Price can be supported by subsidies the same way that waste processing is supported by the EU. Therefore, emphasis on biobutanol from waste lignocellulose in blends from waste animal fats in this article increases the sustainability criteria of processed waste under the concept of a circular economy as opposed to sources of biofuels, which are purposely grown in fields.

\section{Acknowledgements}

The paper was created with the grant support project CIGA CULS Prague 20153001 - Utilization of butanol in internal combustion engines of generators. 


\section{References}

1. SENDZIKIENE E., MAKAREVICIENE V., JANULIS P Influence of composition fatty acid methyl esters on smoke opacity and amount of polycyclic aromatic hydrocarbons in engine emissions. Pol. J. Environ. Stud. 16, (2), 259, 2007.

2. SJÖGREN M., LI H., BANNER C., RAFTER J., WESTERHOLM R., RANNUNG U. Influence of physical and chemical characteristics of diesel fuels and exhaust emissions on biological effects of particle extracts: a multivariate statistical analysis of ten diesel fuels. Chem. Res. Toxicol. 9, 197, 1996.

3. ARDONE M., MAZZONCINI M., MENINI S., ROCCO V., SENATORE A., SEGGIANI M., VITOLO S. Brassica carinata as an alternative oil crop for the production of biodiesel in Italy: agronomic evaluation, fuel production by transesterification and characterization. Biomass Bioenerg. 25, 623, 2003

4. HÖNIG V., MILER P., HROMÁDKO J. Bioethanol as a future inspiration. Listy Cukrov. a Reparske 124, (7-8), 203, 2008 [In Czech].

5. HÖNIG V., KOTEK M., MAŘÍK J. Use of butanol as a fuel for internal combustion engines. Agronomy Research 12, (2), 333, 2014.

6. HROMÁDKO J., HÖNIG V., HROMÁDKO J., MILER P., SCHWARZKOPF M. Ethanol utilization in the compression ignition engines. Listy Cukrov. a Reparske 125, (1), 24, 2009 [In Czech].

7. GRABOSKI M.S., MCCORMICK R.L. Combustion of fat and vegetable oil derived fuels in diesel engines. Prog. Energ. Combust. 24, 125, 1998.

8. ZHANG X., PETERSON C., REECE D., HAWS R., MOLLER G. Biodegredability of biodiesel in the aquatic environmnet. T. ASAE 41, (5), 1423, 1998.

9. LAPINSKIENE A., MARTINKUS P. Research on anaerobic biodegradation of fats, biodiesel fuel and diesel fuel in soil medium. Environmental Research, Engineering and Management 1, (35), 30, 2007.

10. EN 14214:2014 Automotive fuels - Fatty acid methyl esters (FAME) for diesel engines - Requirements and test methods.

11. BONDIOLI P., GASPAROLI A, LANZANI A., FEDELI E., VERONESE S., SALA M. Storage Stability of Biodiesel. Ibid. 72, 699, 2001.

12. SENDZIKIENE E., MAKAREVICIENE V., JANULIS P. Oxidation stability of biodiesel fuel produced from fatty wastes. Pol. J. Environ. Stud. 14, (3), 335, 2005.

13. SIMKOVSKY N.M., ECKER A. Effect of Antioxidants on the Oxidative stability of Rapeseed Oil Methyl Esters. Erdol, Erdgas, Kohle 115, 317, 1999

14. JANULIS P., SENDZIKIENE E., MAKARE VICIENE V., KAZANCEV K. Usage of Fatty Wastes for Production of Biodiesel. Environmental Research, Engineering and Management 4, (34), 101, 2005.

15. PEDERSEN J.R., INGEMARSSON A., OLSSON J.O. Oxidation of Rapeseed Oil, Rapeseed Methyl Ester (RME) and Diesel Fuel Studied with GS/MS. Chemosphere 38, (11), 2467, 1999

16. MUŽÍIKOVÁ Z., BARTOŠ P., POSPÍŠIL M., ŠEBOR G. Vapour pressure and oxidation stability of butanol-gasoline blends. Chem. Listy 107, 717, 2013 [In Czech].

17. POSPÍŠIL M., ŠEBOR G., ŠIMÁČEK P., MUŽÍKOVÁ Z. New trends in production of biofuels and their utilization in road transport. Chem. Listy 106, 953, 2012 [In Czech].

18. BRODA M., LEJA K. The microbiological of distilleries in Poland. Pol. J. Environ. Stud. 19, (5), 901, 2010.

19. CAMPOS E.J., QURESHI N., BLASHEK H.P. Production of acetone Butanol ethanol from degermed corn using Clostridium beijerinckii BA 101. Appl. Biochem. Micro+, 553, 2002.

20. GROOT W.J., LANS R.G.J.M., LUYBEN K.Ch.A.M Technologies for Butanol Recovery Integrated with Fermentations. Process Biochem. 27, 61, 1992.

21. MAŘÍK J., PEXA M., KOTEK M., HÖNIG V. Comparison of the effect of gasoline - ethanol E85 - butanol on the performance and emission characteristics of the engine Saab 952.31 turbo. Agronomy Research 12, (2), 359, 2014.

22. LUJAJI F., BERECZKY A., JANOSI L., NOVAK C., MBARAWA M. Cetane number and thermal properties of vegetable oil, biodiesel, 1-butanol and diesel blends. J. Therm. Anal. Calorim. 102, (3), 1175, 2010.

23. HASENHUETTI G.L., WAN P.J. Temperature effects on the determination of oxidative stabilty with the Metrohm Rancimat. J. Am. Oil. Chem. Soc. 69, 525, 1992.

24. EN 590:2013 Automotive fuels - Diesel - Requirements and test method.

25. MAKAREVICIENE V., SENDZIKIENE E., JANULIS P. Usage of new raw materials for biodiesel fuel production. New methods, Means and Technologies for Applications of Agricultural Products. Proceedings of Int. Conference. Raudondvaris, pp. 52-57, 2003

26. MUŽÍKOVÁ Z., ŠIŠKA J., POSPÍŠIL M., ŠEBOR G. Phase stability of butanol-gasoline blends. Chem. Listy 107, 638, 2013 [In Czech].

27. HROMÁDKO J., HROMÁDKO J., MILER P., HÖNIG V., ŠTĚRBA P. Use of bioethanol in combustion engines. Chem. Listy 105, 122, 2011 [In Czech]. 
